\title{
Differences in Adoption of Introduced Technologies in the Niger Delta Area of Nigeria
}

\author{
Nwachuwku, E.O \\ Alvan Ikoku Federal College of Education, Owerri, Nigeria \\ Onweagba, A.E \\ Imo State University, Owerri, Nigeria \\ Nwajiuba, C. \\ Imo State University, Owerri, Nigeria \\ Doi:10.5296/jsr.v4i2.4523 URL: http://dx.doi.org/10.5296/jsr.v4i2.4523
}

\begin{abstract}
This study examined the differences in adoption of introduced technologies by Agricultural NGOs in the rural Niger Delta area of Nigeria. Purposive sampling technique was use to select nine (9) registered functional and active Agricultural NGOs in the Niger Delta States, while a sample size of 450 farmers and 27 extension field staff were selected using random sampling techniques. A four-point Likert-Type rating scale of questionnaire was used to obtain responses from the various groups of respondents and descriptive statistics were used to analyze data obtained from the study. The result of the study indicates that differences existed in the levels of adoption of introduced technologies by farmers across the Niger Delta states. It was recommended that sustained effort towards exchange of knowledge, resources, ideas and innovations among the NGOs could help in bridging the gap and that the non-agricultural NGOs operating in the region should be encouraged to get involved in agricultural development programmes. This could be done through proper enlightenment programmes, legislation, and policy guides, and would help consolidate the socio-economic gains recorded.
\end{abstract}

Keywords: Adoption of Technologies, Agricultural NGOs.

\section{Introduction}

The provision of extension services through the public extension systems, such as the Ministry of Agriculture Extension Division, the Agricultural Extension Research and Liaison Services (AERLS), and the Agricultural Development Programmes (ADPs), has not been able to make the desired impact on rural farmers (Okoro, 2000). This is attributable to the presence of unskilled professionals, management problems, absence of suitable motivational factors, slow pace of rural infrastructural development, socio-economic bottle-necks, political considerations, low extension agent- clientele ratio, logistic problems, as well as general lack 
of commitment on the part of extension stake-holders. These lead to the emergence of inefficient extension system (Asiabaka, 2002). This informs the need to involve private extension service providers such as the Non-Governmental Organizations (NGOs) and Multinational Companies, to provide private sector extension services to the communities where they operate. Hence there is need for a change from the traditional transfer of technology model (TOT), to a more professional extension system, where those who need extension services seek them, and not extension seeking the client. Thus the system is empowered to become demand-driven, as opposed to supply-driven.

Adoption is believed to be a socio-psychological decision-making process experienced by an individual, in accepting an introduced agricultural innovation or technology. Moshe (1978) stated that adoption of an idea involves a series of complex unit acts. Egbule (2004), in his own contribution, observed that adoption is a decision to continue full use of an innovation, and that only repeated use indicates that adoption has actually taken place. The process consists of at least five stages, which include: awareness, interest, evaluation, trial, and repeated use or rejection, he concluded. Adoption of new ideas is related to improved standard of living (Ekong 2003). The implication is that through adoption, relevant social changes take place. These include changes in skill, knowledge and living conditions, increased personal contact with extension, willingness to seek information, etc. Rate of adoption may however be affected by factors such as farmers' available resources, personal values, educational attainment, economic consideration, real and anticipated profit ability, conformity with existing practice, complexity, among others. Therefore this study was geared towards assessing the differences in adoption of introduced technologies in the by farmers in the Niger delta area of Nigeria

\section{METHODOLOGY}

The study population consisted of the participating farmers registered with the various NGOs in the study area, as well as the Extension Agents of the agricultural NGOs. Purposive sampling technique was use to select one NGO from each of the Nine (9) Niger Delta States registered functional and active Agricultural NGOs, making a total sample size of 9 NGOs. This was because the NGOs satisfied the researcher's pre-determined criteria for selection, with regard to functionality and active involvement in agricultural activities in the area.

One Local Government Area and two farming communities were purposively chosen from each of the states. Twenty-five farmers and 3 extension field staff of the NGOs were selected from each of the communities through random sampling technique. These gave a sample size of 450 farmers and 27 extension field staff. A four-point Likert-Type rating scale of questionnaire was developed and used to obtain responses from the various groups of respondents. Two sets of questionnaires were distributed to the two groups of respondents. Descriptive statistics (frequency tables, percentages and mean) were used to analyze data obtained from the study.

\section{RESULTS AND DISCUSSION}

The data on the table tested the hypothesis, which stated that no significant differences in the 
levels of adoption of technologies across the states, in the study area. The result in the analysis of variance table revealed that significant differences existed in adoption rate across the Niger Delta states, at $5 \%$ level of significance $(\mathrm{F}=2.874, \mathrm{P}<0.05)$. The finding nullified the null hypothesis, meaning that significant differences existed in the levels of adoption of technologies across the states, in the study area. This difference in adoption could be attributed to differences in environmental factors, as well as other socio-economic factors in the States. This finding corroborates the opinion of Eze (2005), which identified specific innovation characteristics that influence innovation-decision and adoption among farmers to include; cost relative advantages, compatibility, complexity, triability, observability and divisibility. The implication is that not every farmer or group of farmers can adopt innovation at the same rate, and differences exist among those who adopt easily and those who wait, in the pretext of investigating the innovation.

The Duncan multiple range test, was employed to show whether significant differences existed in the mean adoption scores in the various states. The alphabets "a", "b", "c", "d", and "e" in table 2 were used to separate significant mean adoption scores across the states, and to compare the differences between the means. The table showed significant difference in the mean adoption between Bayelsa state (19.92), and Ondo state (22.06) on the one hand, and Bayelsa and Abia state (23.24) on the other. However, there were no significant differences in adoption in Rivers, Akwa Ibom and Cross River. Also, there were no significant differences in adoption in Edo, Imo and Delta states. Agbamu and Waziri (2007), employed a similar test in their study of marketing of Garri in Delta State of Nigeria; the Implication for Agricultural Development. The differences in adoption could be due to differences in agro-ecological conditions, levels of commitment to extension duties, funding, motivating factors among others.

The highest adoption score (23.24) in Abia may be due to the strong physical and institutional infrastructures, made possible by the presence of numerous research institutions in the state, as well as the favourable agro-ecological conditions, prevalent in the state. Bayelsa State had the least adoption score, followed by Rivers State. The result is expected because the magnitude of hostilities and youth restiveness appear to be higher in these two states, among other factors. The result suggested lack of sustained decision to practice the technology in these states, until otherwise discouraged by prevailing conditions. This could be part of the reason for slower rate of technology integration in the farming enterprise of the states. Previous studies by Asiabaka (2002), identified different adoption categories among the rural farmers, based on their ages, income status, marital status, educational levels, etc. 


\section{Macrothink}

Table 1: ANOVA table indicating whether differences existed

in adoption rates across the Niger Delta states

\begin{tabular}{llllll}
\hline & Sum of square & df & $\begin{array}{l}\text { Mean } \\
\text { square }\end{array}$ & F & Sig \\
\hline Between groups & 475.591 & 8 & 59.449 & $2.874^{*}$ & .004 \\
Within groups & 9123.520 & 441 & 20.688 & & \\
\hline Total & $\mathbf{9 5 9 9 . 1 1 1}$ & $\mathbf{4 4 9}$ & & \\
\hline
\end{tabular}

Source: Field Survey Data 2008

Table 2: Duncan test of differences between means across the states

\begin{tabular}{lll} 
State & Mean adoption scores \\
\hline Bayelsa & - & $19.92 \mathrm{a}$ \\
Rivers & - & $20.06 \mathrm{~b}$ \\
Akwa Ibom & - & $20.18 \mathrm{~b}$ \\
Cross River & - & $20.92 \mathrm{~b}$ \\
Edo & - & $21.44 \mathrm{c}$ \\
Imo & - & $21.56 \mathrm{c}$ \\
Delta & - & $21.82 \mathrm{c}$ \\
Ondo & $-22.06 \mathrm{~d}$ \\
Abia & $-23.24 \mathrm{e}$ \\
\hline
\end{tabular}

Mean scores with differing alphabets are significant at 0.05 level

Source: Field Survey Data 2008

\section{CONCLUSION}

The differences in adoption of introduced technologies in the Niger Delta area of Nigeria were investigated. The result of the study indicates that differences existed in the levels of adoption across the Niger Delta states. These differences in adoption could be attributed to differences in agro-ecological conditions, levels of commitment to extension duties, funding, motivating factors; socio-economic characteristics of the farmers among others. It can also be concluded that most of the introduced technologies such as crop production technologies, livestock and fisheries, agro-forestry, as well as soil management practices had been put to full scale use. 


\section{RECOMMENDATIONS}

Based on the findings of the study, the following recommendation has been made:

i. Sustained effort should be geared towards the decision to practice the introduced technologies in these states

ii. The Agricultural NGOs should be encouraged to expand their areas of coverage of extension activities within the rural setting. Similarly, the non-agricultural NGOs operating in the region should be encouraged to get involved in agricultural development programmes. This could be done through proper enlightenment programmes, legislation, and policy guides, and would help consolidate the socio-economic gains recorded.

iii. Most of the identified constraints could be solved through exchange of knowledge, resources, and ideas among the NGOs.

\section{REFERENCES}

Asiabaka, C. C. (2002). Agricultural Extension. A Handbook for Development Practitioners. Molsyfem United Services. Omoku (1-160).

Egbule, P. E. (2004). Fundamentals and Practice of Agricultural Education. Totan Publishers Ltd. Owerri (pp 263).

Ekong, E. E. (2003). An Introduction to Rural Sociology. Dove Educational Publishers, Uyo. (pp 404).

Mosher, A. J. (1978). An Introduction of Agricultural Extension, New York. Agricultural Development Council.

Okoro, F. (2000). "Sustaining Agricultural Extension Services Through Private Participation: Issues and Policy Implication". In Nwosu A. C., C. U. Nwajiuba and J. A. Mbanasor (eds), Agricultural Transformation in Nigeria: Proceedings of a National Conference. FUA Umudike. P.89. 